\title{
АГАТАНГЕЛ КРИМСЬКИЙ - БАГАТОГРАННА ТВОРЧА ОСОБИСТІСТЬ
}

\section{Поляруш Н. С., Хоцянівська І. В.}

\section{ВСТУП}

Актуальність теми дослідження зумовлена необхідністю глибокого і всебічного вивчення багатогранного творчого доробку Агатангела Юхимовича Кримського, одного із видатних представників в історії світової науки i культури, людини різнобічно обдарованої та енциклопедично освіченої, поліглота. За походженням - кримський татарин, що стояв біля витоків формування Української Академії наук i все своє життя присвятив науці; людина, яка знала понад шістдесят мов $\mathrm{i}$ всі діалектні особливості української мови. Він належить до блискучої плеяди подвижників української науки і культури другої половини XIX початку XX століття, діяльність і творчість якого стали невід'ємною складовою частиною українського сходознавства, славістики, літератури, фольклору, історії, етнографії, культури. Наукова і творча спадщина А. Кримського становить понад тисячу праць. Серед них - монографії, підручники, статті, повідомлення, рецензії, оригінальні та перекладні художні твори, роман «Андрій Лаговський», збірки оповідань «Повістки i ескізи з українського життя», «Бейрутські оповідання» і поетична збірка «Пальмове гілля», що збагатили українську літературу.

Життя i творчість А. Кримського вивчали: Л. Лопатинський, Б. Грінченко, I. Нечуй-Левицький, О. Грушевський, Г. Хоткевич, I. Франко, М. Возняк, М. Свшан, Леся Українка, Я. Білоштан, M. Рильський, О. Бабишкін, П. Колесник, С. Шаховський, К. Гурницький, С. Білокінь та інші. У наш час цю справу продовжують: М. Веркалець, В. Шевчук, О. Пріцак, Н. Поляруш, Т. Гундорова, Л. Грицик, Н. Данилюк, Я. Поліщук, Т. Маленька, С. Павличко, Ю. Кочубей, Р. Ткаченко, М. Моклиця. I хоча дослідники частково торкалися окремих аспектів художньої спадщини письменника, проте, $\mathrm{i}$ досі не все вирішено 3 оцінками майстерності письменника, 3 його приналежністю до тієї чи іншої течії, не до кінця визначена й художня цінність творчого спадку А. Кримського тощо. 


\section{1. Генеза та естетична природа художнього мислення письменника}

Агатангел Юхимович Кримський - один із найяскравіших представників в історії світової науки і культури, людина різнобічно обдарована та енциклопедично освічена, поліглот. І. Франко подає широку характеристику усього доробку А. Кримського: «А. Кримський - високооригінальна поява в нашій літературі. Чи пише він суто філологічні статті, чи літературні критики, чи прозові оповідання, чи поезії, всюди вносить своє власне в такій мірі, як мало котрий наш письменник» ${ }^{1}$. За словами С. Павличко, «він був людиною короткої епохи, яка називалася "fin de siècle"2. Дослідниця віднесла А. Кримського до тієї доби, котра позначена в українській літературі новітніми мистецькими пошуками. Науковиця наполягає, що А. Кримський «найглибше відчув, пережив i найсміливіше втілив у літературних формах типові європейські дискурси перелому віків дисгармонію людської душі, іiі діонісійства, декадентського гедонізму, екзотичних пристрастей...» ${ }^{3}$. Ім'я А. Кримського відоме практично у всіх арабських i центральноазіатських країнах, дружбою 3 ним пишались Іван Франко і Леся Українка. Відомо, що на знак пошани до вченого Леся Українка присвятила йому поему «В катакомбах», ділилася 3 ним своїми творчими планами, радилася у східних питаннях. Лев Толстой завдяки його працям відкрив для себе філософію Сходу.

Сторіччя 3 дня народження (1971 р.) видатного оріснталіста, історика, філолога i літературознавця за рішенням ЮНЕСКО відзначалось як подія світового значення ${ }^{4}$. Його можна було б вважати поліглотом номер один на планеті. Та, на жаль, А. Кримський сам не міг точно сказати, скільки мов знає. На запитання, скільки і які мови він знає, жартома відповідав, що йому легше перерахувати ті, яких не знає. У листі до Б. Грінченка, однак, поділився: «Слов'янські знаю добре всі, разом з літературними наріччями. Само собою розуміє ться, що добре знаю грецьку і латинську, а філологічно - санскрит... Германські - зовсім добре німецьку й англійську, гірше - голландську і датську... Романські - зовсім добре французьку і італійську, зле іспанську... І Із іранських мов добре знаю тільки перську (почасти з їі наріччями)... Із семітських мов зовсім добре знаю староарабську і новоарабську (сірійське наріччя знаю так, що говорю ним, а другі

${ }^{1}$ Франко І. Наша поезія у 1901 р. ЛНВ. Львів, 1902. Кн. 2. С. 116.

2 Павличко С. Націоналізм, сексуальність, орієнталізм: складний світ Агатангела Кримського. Київ, 2001. С. 46.

${ }^{3}$ Там само.

${ }^{4}$ Пилипенко Л., Рященко Д. Агатангел Кримський: реабілітований посмертно. Наукові записки Вінницького державного педагогічного університету ім. Михайла Коцюбинського. Сер. Історія. Вінниця, 2010. Вип. 18. С. 121. 
новоарабські наріччя знаю теоретично). Філологічно знаю мову жидівську і арамейську... Грузинську вчив, але багацько з неї забув... 3 урало-алтайських мов знаю турецько-татарську. Найкраще, розуміється, знаю наріччя османське, бо доводиться завсігди мати практику... Міг би додати, що єсть ще й такі мови, які я розумію більшменш, хоч і не вчив їх (наприклад, португальську...)» 5 .

Як відомо, Кримський був українцем не за походженням, а за свідомим вибором. Він створив свою українську ідентичність власними руками, точніше, власними інтелектуальним зусиллям і почуттями ${ }^{6}$. Ця ідентичність має обмаль «генетичних», «кровних» підстав. Сам А. Кримський стверджував, що «у мені й кровинки української немає: мати моя - українська полька, а батько - білорус... Я родився і виріс на Вкраїні та й українізувався» ${ }^{7}$. Формування національної ідентичності А. Кримського відбувалося поступово під впливом низки важливих факторів. Так, перша стадія його самоукраїнізації характеризується знайомством 3 розмовною мовою, носієм якої $є$ український народ, зокрема селяни ${ }^{8}$. Ця стадія не могла бути глибокою, бо навіть ті люди, які розуміли та знали українську мову, не мали чітко окреслені політичні орієнтири. Саме тому друга - інтелектуальна й політична фаза самоукраїнізації - створила Кримського. Вона бере свій початок 3 навчання автора в Києві, у Колегії Галагана. За словами С. Павличко, колегіат Кримський почувався мужиком, бідняком, а тому українцем ${ }^{9}$.

У листі до І. Франка він пише: «Я, як і другі стипендіанти, дуже рано мусив пізнати, що я «поганого роду», «неблагородний», що в мене кров не така, як у «вищої породи (себто в дворян та багатирів)» ${ }^{10}$. Його зброєю були знання: «Я в колегії був первим учеником, гордощі розвелися в мені незмірно, тому-то, хоч я себе поставив одразу так, що наші аристократи не сміли чіпати мене, слабого...» ${ }^{11}$.

У колегії А. Кримський активно випробовує свої сили на літературній ниві, пише вірші, оповідання, займається перекладацькою діяльністю, публікується в рукописному журналі «Коллегиатская

5 Бурбан В. Майже забутий незбагнений Агатангел Кримський. Наука $i$ суспільство. 2006. № 1-2. С. 32-33.

${ }^{6}$ Павличко С. Націоналізм, сексуальність, орієнталізм: складний світ Агатангела Кримського. Київ, 2001. С. 217.

7 Кримський А. Твори в п’яти томах / ред. кол.: І. Білодід та ін. Київ : Наук. думка, 1972-1974. Т. 5. Кн. 1. С. 59.

${ }^{8}$ Павличко С. Націоналізм, сексуальність, орієнталізм: складний світ Агатангела Кримського. Київ, 2001. С. 218.

${ }^{9}$ Там само. С. 218.

${ }^{10}$ Кримський А. Твори в п'яти томах / ред. кол.: І. Білодід та ін. Київ : Наук. думка, 1972-1974. Т. 5. Кн. 1. С. 39.

${ }^{11}$ Там само. С. 60. 
мысль». Великий вплив на формування світогляду А. Кримського під час навчання справив П. Житецький.

У цей період за сприяння I. Франка й М. Павлика утверджуються політичні погляди А. Кримського. На формування світогляду А. Кримського великий вплив мали праці М. Драгоманова. Спочатку ідеї М. Драгоманова він характеризує як «нове світло осіяло» ${ }^{12}$. Проте згодом А. Кримський критикуватиме М. Драгоманова за брак націоналізму, зокрема у своїх листах до Б. Грінченка.

Б. Грінченко вважав А. Кримського борцем за національну й народну справу, своєю чергою останньому потрібен був товариш іпорадник. Листи до Б. Грінченка допомагали поставити конкретні запитання й знайти на них відповіді ${ }^{13}$. Згадуючи юні роки, А. Кримський самокритично оцінював шляхи пошуку істини: «Натомість я вдався до політикування і понаробляв таких помилок, що тепер мені невимовно соромно згадувати про них» ${ }^{14}$. М. Павлику А. Кримський писав, що «коли помилявся, то помилявся щиро, та й то дякуючи своїм вкрай розщурбованим нервам» ${ }^{15}$. Один 3 найяскравіших учнів А. Кримського О. Пріцак стверджує, що «професор П. Житецький заступив йому батька, а письменники й I. Франко стали його братами-сповідниками» ${ }^{16}$.

У 1889-1892 рр. А. Кримський вчиться в Москві, в Лазаревському інституті східних мов. Там він грунтовно вивчає арабську, фарсі, турецьку мови та літератури i їхній вплив на українську та інші слов'янські мови, особливо тих народів, що потрапляли в залежність від Османської імперії. У листі до О. Огоновського А. Кримський писав: «Перші $1 \frac{1}{2}$ року мені довелося дуже пильно працювати над сухим вивченням лексичного матеріалу східних мов. Робота була дуже важка, дарма що в мене чудова пам'ять. До того ж рівночасно я студіював деякі правничі науки, що стосуються до історії та етнографії» ${ }^{17}$.

У студентські роки А. Кримський друкує в галицьких виданнях науково-критичні й публіцистичні статті, рецензії, переклади, матеріали про культурне життя в Росії, а в російській пресі - про життя Галичини. Крім кількох збірок віршів, А. Кримський написав

${ }^{12}$ Там само. С. 65

13 Тищенко К., Сватко А. Національна ідентичність Агатангела Кримського (на матеріалі полеміки з Михайлом Драгомановим). Молодий вчений. 2017. № 6.1. С. 95.

${ }_{14}$ Кримський А. Твори в п’яти томах / ред. кол.: І. Білодід та ін. Київ : Наук. думка, 1972-1974. Т. 5. Кн. 1. С. 77.

${ }^{15}$ там само. С. 105.

16 Пріцак О. Українець тюркського походження Агатангел Кримський. Шкільна бібліотека. 2006. № 12. С. 125.

17 Кримський А. Твори в п'яти томах / ред. кол.: І. Білодід та ін. Київ : Наук. думка, 1972-1974. Т. 5. Кн. 1. С. 116. 
«Повістки i ескізи 3 українського життя» та роман «Андрій Лаговський», дві частини якого були надруковані 1905 року у Львові. У цей же час А. Кримський налагоджує дружні стосунки, активно листується з багатьма українськими письменниками, вченими, діячами культури: І. Франком, В. Левицьким, О. Огоновським, Б. Грінченком, М. Павликом, Т. Житецьким та ін. А. Кримський активно сприяв виходу у світ творів українських письменників у Москві.

Після закінчення інституту А. Кримський залишається на кафедрі арабської філології для підготовки до професури. У тому ж листі до О. Огоновського А. Кримський пише: «А в мене був намисил: піти ще на один факультет, іменно ж на філологічний, щоб спеціалізуватися на порівнявчій філології, до якої я вже й перше мав велике прихилля, а до того й багатий матеріал (я вже тоді знав щось із п'ятнадцятеро мов, але мав неодмінно вивчити ще скількись)» ${ }^{18}$.

Зі слів самого А. Кримського відомо, що, навчаючись у Лазаревському інституті, він потрапив під нагляд царської охранки. За активне листування 3 «іноземцями» - I. Франком, М. Драгомановим та друкування (через заборону виходу українських книг та журналів у Російській імперії) перших своїх творів за кордоном, у тодішній Австро-Угорщині, він внесений до списку «підозрілих елементів» ${ }^{19}$.

Наприкінці 80-х років А.Кримський починає етнографічне ідіалектологічне вивчення життя населення Шевченкового краю. 31893 року він як член етнографічного товариства бере активну участь у його друкованому органі «Етнографічний огляд», знайомлячи російського читача 3 українським фольклором. За порадою I. Франка стає співробітником вісника літератури, історії і фольклору «Житє і слово». Все, що видавалося А. Кримським 3 питань фольклористики, подавалося емоційно, з ліричними відступами, спогадами, паралелями й асоціаціями, 3 відчуттям часу, з полемічною пристрастю. А. Кримський творчо сприймав традиції попередників (Т. Шевченка, Марка Вовчка, С. Руданського, I. Нечуя-Левицького, I. Франка, Лесі Українки) у використанні народної творчості як одного з важливих позитивних факторів формування власного світогляду і художнього методу. Майстерне використання А. Кримським народно-поетичної української та східної образності стане одним $з$ джерел його новаторства.

18 Кримський А. Твори в п’яти томах / ред. кол.: І. Білодід та ін. Київ : Наук. думка, 1972-1974. Т. 5. Кн. 1. С. 116.

19 Пилипенко Л., Рященко Д. Агатангел Кримський: реабілітований посмертно. Наукові записки Вінницького державного педагогічного університету ім. Михайла Кочюбинського. Сер. Історія. Вінниця, 2010. Вип. 18. С. 122. 
Особливе місце у творчій спадщині А. Кримського посідають праці 3 історії української мови, вироблення теорії культури української мови. А. Кримський першим написав Історичну граматику з української мови, що вийшла в двох томах у Москві 1907 р. Дослідження з української мови - це результат багаторічної копіткої праці вченого. А. Кримський вважав, що головна роль у розбудові національної мови належить народові, оскільки вона збагачується, формується за рахунок діалектів, неологізмів і запозичень.

А. Кримський був одним 3 небагатьох українських поетів, які відчували помітний вплив літератури Близького Сходу. У 18961898 pp. А. Кримського було відряджено до Сирії та Лівану для підготовки до професорського звання 3 арабістики. Результатом глибокого вивчення історії, культури близькосхідних народів стануть написані ним синтетичні огляди арабської, турецької, перської літератур, монографічні праці про поетів різних часів і народів. Мотивами Близького Сходу будуть пройняті його збірки «Пальмове гілля» та «Бейрутські оповідання».

Повернувшись до Москви, А. Кримський викладав курс арабської мови й письменства у тому ж таки Лазаревському інституті. Восени 1900 р. його обирають професором двох кафедр - арабської філології і східної історії. Тут він працював 18 років і водночас редагував кілька видань 3 орієнталістики, як-от: «Древности восточные» («Восточного отдела Московского императорского археологического общества») i «Труды по востоковедению» («Лазаревского института восточных языков»). Останні складалися 326 томів монографічних розвідок А. Кримського. Виходять його численні українознавчі розвідки, поетичні й белетристичні твори. Науковий доробок московського періоду життя А. Кримського приголомшує свойм різноманіттям.

У 1918 році на запрошення нової влади А. Кримський переїжджає до Києва, де протягом 1918-1921 рр. очолює кафедру україністики, читає лекції з історії української мови та $є$ професором всесвітньої історії Київського університету. Він став одним із засновників і перших академіків Української академії наук, першим ії неодмінним секретарем.

Політики А. Кримський намагався уникати. Проте нова влада не могла не зважати на ученого зі світовим авторитетом. Як відомо, влада в Україні постійно змінювалася й часто вона була ворожа концепції української науки. Весною 1920 р. щойно обраний депутатом Київради академік лише дивом уникнув смерті: А. Кримський надав притулок у своїй квартирі більшовику С. Григоруку. А. Кримського звинуватили у ще важчому злочині: виданні підпільної газети (польською мовою) «Глас комуніста». За словами дослідників Л. Пилипенко й Д. Рященко, заарештованого академіка привели у двір Академії і поставили біля 
стіни, вишикувавши навпроти розстрільну команду. I хоча це було лише імітацією розстрілу, перенесений стрес мало не коштував йому повної втрати зору ${ }^{20}$.

Тридцяті роки XX століття видалися ще важчими. У зв'язку 3 погіршенням стану здоров'я та посиленням бюрократизації та ідеологізації науки і освіти А. Кримський, якого публічно радянська влада звинуватила в націоналізмі, повністю відійшов від адміністративної та наукової діяльності, вів замкнений спосіб життя. Коли почалася Друга світова війна А. Кримського безпідставно заарештували. У лютому 1942 р. справу проти А. Кримського, який ні на одному допиті винним себе так і не визнав, було припинено - через смерть підслідного. Тут можна тільки повторити слова I. Іллєнка: «Слід віддати належне Агатангелу Юхимовичу, який, незважаючи на похилий вік і недугу, знайшов у собі сили, вичерпав їх останній запас, але не піддався, не обмовив ні себе, ні товаришів, достойно доніс свій тяжкий хрест на Голгофу народної покари» ${ }^{21}$.

За словами Є. Ломонос, після закінчення війни А. Кримського розшукував його названий син Микола Агатангелович Кримський. Та куди б не звертався М. Кримський, звідусіль надходили стандартні відписки: «Никаких сведений о судьбе вашего отца не имеем». I лише наприкінці 50-х рp. він отримав такий документ: «После дополнительной проверки, проведённой Комитетом Государственной Безопасности УССР, Прокуратура по делу Крымского А.Е. от 23 мая 1957 года производство прекратила за отсутствием в его действиях состава преступления. Таким образом Крымский А.Е. полностью реабилитирован» ${ }^{22}$. Проте на реабілітацію наукової спадщини А. Кримського українська та світова наукова спільнота не дочекались i донині. О. Пріцак - науковець світового масштабу, аспірант А. Кримського - наголошував, що АН України залишається у великому боргу перед iї першим Неодмінним Секретарем. У зв'язку з цим він ще у 1991 р. пропонував, щоб Академія підготувала і видала Повне зібрання літературних та наукових творів А. Кримського та його епістолярну спадщину ${ }^{23}$. Проте ці пропозиції не реалізовані і дотепер.

${ }^{20}$ Пилипенко Л., Рященко Д. Агатангел Кримський: реабілітований посмертно. Наукові записки Вінницького державного педагогічного університету ім. Михайла Коиюбинського. Сер. Історія. Вінниця, 2010. Вип. 18. С. 123.

${ }^{21}$ Етнонаціональний розвиток України. Терміни, визначення, персоналії. Київ : Інститут держави і права АН України / ред. кол. : Ю. Римаренко, І. Курас, І. Дзюба та ін. Київ, 1993. С. 70.

22 Ломонос С. Широкосвіте життя Агатангела Кримського. Дивослово. 2002. № 1. C. 49-50.

${ }^{23}$ Пріцак О. Наші Ньютони та Галілеї. День. 2010. 19-20 березня. С. 25. 
Отже, багатогранна творча натура А. Кримського, для котрого невблаганна праця була синонімом життя, посідає чільне місце в літературному процесі кінця XIX - початку XX століття. Відомий учений-сходознавець, рівного котрому за обсягом праці не було, етнограф і фольклорист, відомий дослідник української мови, автор численних праць 3 історії української літератури різних часів, критик, поет і прозаїк, перекладач зі східних і західних мов, перший секретар Української Академії наук. За розміром діяльності його можна порівняти 3 самим I. Франком. Його творчий внесок до скарбниці української культури й науки $є$ неоцінений та беззаперечний i тому потребує грунтовного вивчення.

\section{2. Особливості рецепції літературної творчості А. Кримського}

Кінець XIX - початок XX століття - це період оновлення літературного дискурсу, в основному на рівні проблематики й тематики, мотивів та сюжетів, яке відбувалося за рахунок залучення інтернаціонального мистецького досвіду, європеїзації літератури, а також зацікавлення екзотичним Сходом. У своїх дослідженнях літературно-культурний критик Е. Саїд наголошував на тому, що в Свропі наприкінці XIX - початку XX століть престижним було займатися орієнталістикою. У цій галузі все більше зростала кількість лінгвістичних досліджень, крім того, західні академічні сходознавці почали говорити про орієнталізм як про літературний жанр: «Орієнталізм - це школа інтерпретації, предметом якого є Схід, його цивілізації, народи і характерні риси» ${ }^{24}$.

В європейській поезії філоорієнталізм (відкриття i початок глибокого вивчення Сходу) пов'язують насамперед із романтизмом. Починаючи 3 єнських романтиків (Ф. Шлегель, Ф. Новаліс, Л. Тік і пов'язані 3 ним Ф. Шеллінг і Й. Гельдерлін) в європейській традиції приживлюються не лише окремі образи й художні форми Сходу, а й цілі сюжети. Мотиви інтелектуально-духовної втечі на Схід, пошуки Сходу як прихистку, душевного раю услід за Гете розвиваються в поезії французького модерну. Щире захоплення Сходом (Ш. Бодлер, А. Рембо) виявляється i в інших літературах, даючи орієнтальний поштовх, зокрема, російським символістам, акмеїстам та неоромантикам (А. Бєлий, О. Блок, В. Соловйов, М.Гумільов). В Україні до екзотичних орієнтальних реалій почали звертатися ще початківці українського романтизму (Л. Боровиковський, I. Срезневський, Є.Гребінка, А. Могила). Поодинокі

24 Саид Э. Ориентализм. Западные концепции Востока / пер. с англ. А. Говорунова. Санкт-Петербург, 2006. С. 313. 
інонаціональні мотиви присутні і у творчості романтиків харківської школи, зокрема в поезії М. Костомарова («Максим Перебийніс», «Давнина», «До Марії Потоцької» та інші) та О. АфанасьєваПотоцького («Шевченкові», «Прощання», «К Тереку»). Поетична творчість Т. Шевченка також презентувала широкий діапазон інонаціональних мотивів та образів, що неабияк збагатило український літературний словник. Можемо стверджувати, що вже на початку XIX ст. українські митці активно осмислювали екзотичне та переносили його на український грунт. Модернізм повторює тенденцію романтизму щодо трансформації екзотичного й свідомо адаптує східні мотиви для українського тексту 3 метою зацікавити читача інокультурою та психологією інших народів. Інонаціональні мотиви присутні у творчості І.Франка, Лесі Українки, О. Кобилянської, П. Карманського тощо.

Безперечним авторитетом у галузі сходознавства і дотепер залишається А. Кримський - один із натхненних класиків українського мистецького слова, в часи його найвищого розквіту на грані XIX та XX століть, він належав до блискучих знавців класичної арабської та перської - не тільки літератур, а й цілих культур. Цей рідкісний талант дав А. Кримському можливість відчувати та творити гармонічно і паралельно у двох структурах поетичного мислення. I. Франко виділив А. Кримського як «відомого орієнталіста», котрий «дав українській літературі книжку прозовихоповідань, середяких "Рsychopathia nationalis", що відрізняється яскравістю фарб і глибинним ліризмом ${ }^{25}$.

Як відомо, А. Кримський прожив на Сході лише два роки, проте він постійно переносився туди уявою, і не тільки в Сирію та Ліван, а й в ті країни та епохи, які досліджував. Схід, зокрема, східна поезія i література, виявилися тим простором свободи, якої так бракувало А. Кримському в його реальному житті. До якоїсь міри в студіях Сходу він компенсував цю нестачу. Частково цим пояснюється емоційний тон багатьох творів А. Кримського з приводу окремих ситуацій або героїв.

А. Кримський любив Схід, любив Омара Хайяма й Гафіза, Румі й Сааді. Йому подобалися східні анекдоти, пряний східний гумор та філософські роздуми про марноту буття. Його інтригували й приваблювали суфії-дервіші, які ставали свого роду зразком самоідентифікації. С. Павличко, розглянувши «Екзотичну подорож на Схід» А. Кримського, пише: «Око Кримського бачило не лише незвичайну для українського зору природу, яка йому дуже подобалася, але й перипетії політичного, релігійного, дипломатичного життя в Бейруті, й шокуючі європейця звичаї: антисанітарію, «дикі» традиції

${ }^{25}$ Франко І. Зібр. творів : у 50 т. Київ, 1984. Т. 41. С. 154-155. 
місцевого люду, «простоту» в їжі, гігієні, зокрема відправлянні природних потреб, фальш, брехливість, хитрість мешканців Бейрута, цинізм та розпусту місцевих попів i монахів та багато іншого. Найбільш відверті деталі місцевого побуту наводилися в листах до брата, а не до батька чи сестри» ${ }^{26}$. Дослідниця стверджує, що саме орієнтальна компонента допомогла пролити світло на індивідуальну вдачу самого А. Кримського.

У листах А. Кримський часто критикував норови та звичаї мешканців Сходу. Зокрема, у листі до Ю. Кримського він пише про арабську їжу, до якої дуже важко звикнути звичайному європейцю: «... Но пока что это не горе, а непривычная пища. Чаю здесь нет, борща нет. Говядины здесь не едят, не любят, а едят баранину, и то в самом малом количестве. Почти вся пища растительная. ... Здесь чаю не пьют..., супа тоже нет... Несчастье для непривычного здесь и с хлебом. Такого хлеба, как у нас, здесь нет: вместо того пекут лепёшки, вроде коржей или блинов; они тягучи и неудобны» ${ }^{27}$. Дратували А. Кримського й повне безкультур'я та негігієнічна поведінка місцевих жителів за столом: «К обеду мне сегодня приготовили прекрасный суп с вермишелью. Я собирался насладиться этим новым для меня здесь блюдом..., но оно оказалось горячим. Хозяин, врач, не доверяя мне, вложил весь свой мохнатый палец в средину моей тарелки и тогда со мной согласился. Я с трудом себя принудил после того съесть половину тарелки, да и то ел лишь из страха, что подумают, будто это блюдо мне не по вкусу и не следует его больше готовить» ${ }^{28}$. А. Кримський також наголошує на жахливому соціальному становищі жителів Бейрута: «Мои хозяева - люди бедные, квартира плохая. Полы везде каменные, и мой ревматизм возобновился... Этой болезнью страдают и туземцы; простуды с ревматизмом боятся и они» ${ }^{29}$. Загалом у період життя в Бейруті А. Кримський написав близько 150 листів і ще 330 листів написав своїм колегам - ученим і письменникам у Галичину i в Росію. Ці листи за своїм жанром неоднозначні. Дослідниця С. Павличко називає їх щоденником, а також відносить їх до жанру мандрів у екзотичних країнах.

Багато важить поетична збірка А. Кримського «Пальмове гілля. Екзотичні поезії» (1898-1908), завдяки перенесенню поетом на рідний

26 Павличко С. Націоналізм, сексуальність, орієнталізм: складний світ Агатангела Кримського. Київ, 2001. С. 183-184.

27 Кримський А. Твори в п'яти томах / ред. кол.: І. Білодід та ін. Київ : Наук. думка, 1972-1974. Т. 5. Кн. 2. С. 16-17.

${ }^{28}$ Т ам само. С. 42.

29 Кримський А. Твори в п'яти томах / ред. кол.: І. Білодід та ін. Київ : Наук. думка, 1972-1974. Т. 5. Кн. 2. С. 16. 
грунт арабських і перських форм, органічному засвоєнню ним пам'ятки близькосхідного фольклору. Недарма I. Франко вважає його «першим піонером нашого слова на сій просторій i досі майже не ораній українським лемішем ниві східної поезії» ${ }^{30}$. Крізь призму сприймання Кримського-поета своєрідно на тлі неповторної і багатої природи Близького Сходу розкривається «діалектика душі» ліричного героя «Пальмового гілля». Колоритність пейзажів у збірці забезпечується не лише панорамністю у зображенні незвичайних краєвидів та художньою точністю в передачі деталей, відтіненні кольорів і барв, а й щедрим, раніше не відомим в українській поезії відтворенням екзотичних «пахощів» Сходу. Нового емоційного забарвлення набувають картини природи у «Пальмовому гіллі», коли автор урізноманітнює їх пейзажами і побутовими деталями України, коли майстерно переплітає у своїх поезіях близькосхідне народнопоетичне бачення 3 суто українським. С. Павличко пише: «На фоні дещо аморфного любовного дискурсу кінця 1890-х років - початку XX століття любовна мова А. Кримського зазвучала свіжо й оригінально» ${ }^{31}$. О. Пріцак стверджує, що «Пальмове гілля» Кримського-поета - це своєрідний жанр. Поодинокі його поеми i цикли - не тільки художні i не тільки філологічні переклади. Це «орієнтально» інспіровані i, крім того, структурно по-«орієнтальному» відчутні перлини українського ліричного генія. «Пальмове гілля» - це також своєрідний жанр у світовій літературі ${ }^{32}$.

До читання цієї збірки заохочував І. Франко як до «поважного і тривкого надбання нашої літератури», як до книги, багатої змістом, різнорідної незвичайними, новими поетичними формами. Звертаючись у своїй книзі віршів до теми кохання, минущості життя, Кримський продовжував традиції української поезії. Як відомо, геніальне втілення інтимна тема знайшла в «Зів'ялому листі» I. Франка, який зумів глибоко розкрити всі складнощі і суперечності великого людського почуття. Прагненням розкрити межі ліричного відтворення внутрішнього світу людини відзначається і цикл поезій Осипа Маковея “Semper Idem” («3 теки скептика»), своєрідність якого виявилась у гумористичному висвітленні переживань закоханих. За схемою «Зів'ялого листя» формально йшов П. Карманський («3 теки самовбивця〉). Вважаємо, що за глибиною психологічного аналізу

${ }^{30}$ Франко І. Зібр. творів : у 50 т. Київ, 1976. Т. 33. С. 188.

31 Павличко С. Націоналізм, сексуальність, орієнталізм: складний світ Агатангела Кримського. Київ, 2001. С. 69.

32 Пріцак О. Українець тюркського походження Агатангел Кримський. Шкільна бібліотека. 2006. № 12. С. 43. 
збірка Кримського «Пальмове гілля» найближче стоїть до «Зів'ялого листя» Івана Франка. Вона також має циклічну будову, де назви циклів певною мірою розкривають ї ідейне спрямування. Як і в «Зів'ялому листі», почуття кохання у віршах А. Кримського втілюється в різних образах: кохання - «рабське почування», «страшний злочин», «кохання - свято». Поет зумів художньо переконливо втілити думку про властиву всім людям здатність кохати, страждати ірозчаровуватись. Ліричний герой «Пальмового гілля» подається на тлі неповторної i багатющої природи Близького Сходу, своєрідно переданої крізь призму сприймання українського поета. Це певною мірою притуплює біль героя, заспокоює його, втішає і навіть звеличує. Героєві «Зів'ялого листя» такою розрадою є чарівний світ українського фольклору.

У «Пальмовому гіллі» вміщені й переклади А. Кримського, особливо з поетів Сходу - Гафіза, Омара Хаяма та ін., у яких він виявив себе великим майстром художнього слова, блискучим знавцем мов. Він уперше ознайомив українського читача 3 кращими творами орієнтальних письменників. У листі до I. Франка А. Кримський схвильовано пише: «...тут, у Росії, мені стає аж досадно, що ніхто нічогісінько не тямить про Схід, не знає навіть звичайних речей» ${ }^{33}$. I. Франко високо оцінював А. Кримського-перекладача i завжди заохочував його до цієї праці й направляв: «Ваш Хаям надрукований, хоч вірші вміщені не всі. Що ви думаєте про Фірдоусі? Я думаю, оскільки ви сходознавець, то варто було й хоча б що-небудь перекласти 3 цього великого поета» ${ }^{34}$. Окрім того, саме I. Франко радить А. Кримському доповнити переклади нарисами про життя та творчість орієнталіста та одночасно інформує його про те, як перекладаються твори східної літератури в Західній Європі.

У «Бейрутських оповіданнях» (1897) А. Кримський перетворюється на активного спостерігача за культурно-побутовим життям Сходу, письменник намагається детально ознайомити українського читача 3 побутом, звичаями й життям мешканців Бейрута, цілком відмінного від українського. Лейтмотивом «Бейрутських оповідань» А. Кримського $\epsilon$ зображення європеїзації арабських звичаїв. Як зазначає Г. Останіна, цей мотив має різні форми: думки, почуття, переживання, споглядання, поняття, але наділений однією найважливішою функцією: показати, як чинники та фактори чужоземного походження впливають на розвиток інших народів; яких ідеалів потребують певні нації і як зберегти власну

${ }^{33}$ Кримський А. Твори в п’яти томах / ред. кол.: І. Білодід та ін. Київ : Наук. думка, 1972-1974. Т. 5. Кн. 1. С. 14.

${ }^{34}$ Франко І. Зібр. творів : у 50 т. Київ, 1986. Т. 48-49. С. 262-263. 
традиційну культуру та не втратити національне обличчя, залишитися цікавим світові. У цьому циклі оповідань мотив європеїзації становить гострий конфлікт між традиційними арабськими, французькими та російськими звичаями, у якому немає чиєїсь остаточної перемоги, але й остаточного занепаду норовів Бейрута також не спостерігається, бо, як свідчить текст твору, в них багато захисників національної культури. Такий діалог цивілізацій приводить до культурно-звичаєвого взаємозбагачення народів, відкриває нові світи читачам ${ }^{35}$.

До творчих здобутків А. Кримського належить і роман «Андрій Лаговський» (1919). С. Павличко наполягає, що головною проблемою роману $\epsilon$ любов і сексуальність. Дослідниця пише про те, що ті письменники, які подорожували на Схід, шукали там те, що було недосяжним для Заходу, де «орієнтальний секс» був не винятком: «... на Сході чоловіча бісексуальність нікого не дивує і не переслідується. Безліч разів Кримський прямим і непрямим чином наголошує на цьому у своїх лекціях зі східних літератур, розповідає про свої спостереження за цим феноменом у листах до брата зі Сходу» ${ }^{36}$. Ми погоджуємося, що проблема любові й сексуальності в романі має м ісце, проте вважаємо, що провідною проблемою все-таки є внутрішня потреба самопізнання та саморозуміння головного героя. Саме ця проблема вирішується Андрієм Лаговським під час перебування на Близькому Сході, а також за допомогою детального опрацювання східних джерел, які розкрили йому істинну природу людського життя. Для головного героя важливим $\epsilon$ розв'язання притаманним декадентам конфлікту між «нервами» і здоров'ям, силою i слабкістю, емоційно-романтичного потягу до осіб своєї статі. Андрій Лаговський жив у світі ілюзій і не бачив цінності речей, допоки через східні твори він не усвідомив усю марність своїх внутрішніх переживань.

А. Кримський виявляє терпимість до інокультурної несхожості та своєрідності Сходу, жодного разу не вдається до їдкої іронії чи до сатири. Ліванська «арена» змагань найчастіше описується сходознавцем на рівні внутрішньо-психологічних переживань. Спогад виступає основною формою викладу інформації, де реалістичність зображуваного допомагає засвоїти арабську культуру кінця ХІХ ст. Тобто одним із провідних шляхів формування українського орієнталізму $\epsilon$ довготривалий живий та безпосередній контакт А. Кримського із народами Сходу, де найважливішими виявилися готовність та бажання дослідника пізнати чужий світ. Кримський-

35 Останіна Г. Схід очима Агатангела Кримського. Держава та регіони. Сер. Гуманітарні науки. 2011. Вип. 3. С. 125.

36 Павличко С. Націоналізм, сексуальність, орієнталізм: складний світ Агатангела Кримського. Київ, 2001. С. 89. 
письменник дотримується традиції введення читача у своєрідний колорит Сходу, його побуту та інших реалій. Атмосфера орієнталістики створюється ним за допомогою перекладів, пояснень та тлумачень окремих слів, словосполучень. Як справжній поліглот А. Кримський подає у своїх творах декілька мовних варіантів: грецькі, турецькі, англійські.

I. Франко визначив місце А. Кримського в українській літературі, як: «Друге таке незвичайне явище серед українців (перше Б. Грінченко), незвичайне своєю енергією, любов'ю до України і різносторонністю знань і таланту - це А. Кримський, тепер професор арабської мови 3 Лазаревському інституті східних мов у Москві, філолог за фахом, орієнталіст за покликанням, він виявив себе високоталановитим поетом, дуже оригінальним прозаїком, і якийсь час забирав голос у різних важких літературних і громадських справах у галицьких виданнях ${ }^{37}$.

Отже, орієнтальний вектор прози XIX-XX століть яскраво відбився на творах А. Кримського. Орієнталізм виступив адаптацією, переосмисленням східних сюжетів, мотивів, образів тощо 3 метою оновлення та урізноманітнення рідної культури. А. Кримський виявився тим світочем, що зумів збагатити українську літературу кінця $\mathrm{XIX}$ - початку XX століття новими актуальними проблемами, поглибив традиційні форми роману.

\section{ВИСНОВКИ}

Багатогранній творчій натурі А. Кримського, для якого невтомна праця була синонімом життя, належить своє, ні $з$ ким неподілене місце в українському літературному процесі кінця XIX - початку ХХ століття. Відомий учений-сходознавець, перекладач, ретельний етнограф і фольклорист, уважний дослідник української мови, автор численних праць 3 історії української літератури різних часів, глибокий критик, поет і прозаїк, перекладач із східних мов, перший неодмінний секретар Української Академії наук, один із фундаторів української національної ідеї - таким постає А. Кримський в історії культури нашого народу. Його титанічна праця справді гідна подиву. На жаль, з різних об'єктивних і суб'єктивних причин цілісну творчу біографію вченого і письменника ще не створено. Він і досі належить до найменш прочитаних українських майстрів слова, чию творчість як слід не розглянуто в історії української літератури.

Художня творчість А.Кримського - i поетична, і прозова - не визначила магістральних шляхів розвитку української літератури кінця

${ }^{37}$ Франко І. Зібр. творів : у 50 т. Київ, 1984. Т. 41. С. 515. 
XIX - початку XX століття. Але без його творів наше уявлення про літературний процес того часу було б неповним, бо вони - невід'ємна частина великої української літератури. Агатангел Кримський, як цілком слушно зазначає С. Павличко, «найглибше відчув, пережив і найсміливіше втілив у літературних формах типові європейські дискурси перелому віків - дисгармонію людської душі, іiі діонісійства, декадентського гедонізму, екзотичних пристрастей, саме він найдалі зазирнув у темні глибині людського «я», саме в його творчості Краса і Душа були не ідеальними абстракціями, яким поклонялися.., а цілісною вербальною діяльністю, яку так важко розкласти на риторичні компоненти».

У наближенні українського читача до Близького Сходу багато важили переклади Кримського зі східних мов, які разом з оригінальною поезією «Пальмового гілля» стали своєрідною школою майстерності, вікном до збагачення форми і його оригінальних творів.

\section{АНОТАЦІЯ}

Статтю присвячено Агатангелу Кримському - талановитому письменнику, вченому-орієнталісту, перекладачу, громадському діячу, одному з Фундаторів Академії наук України. Наголошено, що поезія і наука - це два могутні крила таланту невтомного українського ратая на теренах рідної та світової культури. Проаналізовано життєвий та творчий шлях А. Кримського, з'ясовано витоки його письменницького і наукового мислення. Визначено внесок в історію української культури. Розкрито рецепцію творчості А. Кримського його сучасниками. Проаналізовано його творчість у фокусі сучаснихучених. Наголошено, що творчий внесок А. Кримського в українську культуру і науку $є$ безцінним і потребує нового прочитання.

\section{ЛIТЕРАТУРА}

1. Бурбан В. Майже забутий незбагнений Агатангел Кримський. Наука і суспільство. 2006. № 1-2. С. 32-33.

2. Етнонаціональний розвиток України. Терміни, визначення, персоналії. Київ : Інститут держави і права АН України / ред. кол.: Ю. Римаренко, І. Курас, І. Дзюба та ін. Київ, 1993. С. 66-70.

3. Кримський А. Твори в п'яти томах / ред. кол.: І. Білодід та ін. Київ : Наук. думка, 1972-1974. Т. 5. Кн. 1. 546 с.

4. Кримський А. Твори в п'яти томах / ред. кол.: І. Білодід та ін. Київ : Наук. думка, 1972-1974. Т. 5. Кн. 2. 332 с.

5. Ломонос $€$. Широкосвіте життя Агатангела Кримського. Дивослово. 2002. № 1. С. 46-51. 
6. Останіна Г. Схід очима Агатангела Кримського. Держава ma регіони. Сер. Гуманітарні науки. 2011. Вип. 3. С. 119-126.

7. Павличко С. Націоналізм, сексуальність, орієнталізм: складний світ Агатангела Кримського. Київ, 2001. 328 с.

8. Пилипенко Л., Рященко Д. Агатангел Кримський: реабілітований посмертно. Наукові записки Вінницького державного педагогічного університету ім. Михайла Коцюбинського. Сер. Історія. Вінниця, 2010. Вип. 18. С. 120-126.

9. Пріцак О. Наші Ньютони та Галілеї. День. 2010. 19-20 березня. C. $11-26$.

10. Пріцак О. Українець тюркського походження Агатангел Кримський. Пам'ять століть. 2008. № 4. С. 124-142.

11. Пріцак О. Українець тюркського походження Агатангел Кримський. Шкільна бібліотека. 2006. № 12. С. 35-45.

12. Саид Э. Ориентализм. Западные концепции Востока / пер. с англ. А. Говорунова. Санкт-Петербург, 2006. 636 с.

13. Тищенко К., Сватко А. Національна ідентичність Агатангела Кримського (на матеріалі полеміки 3 Михайлом Драгомановим). Молодий вчений. 2017. № 6.1. С. 94-97.

14. Франко І. Зібр. творів : у 50 т. Київ, 1976. Т. 33. 390 с.

15. Франко І. Зібр. творів : у 50 т. Київ, 1984. Т. 41. 680 с.

16. Франко І. Зібр. творів : у 50 т. Київ, 1986. Т. 48-49. 802 с.

17. Франко І. Наша поезія у 1901 р. ЛНВ. Львів, 1902. Кн. 2. С. 116.

Information about the authors: Poliarush N. S., Candidate of Philology Sciences, Associate Profess or at the Chair of Ukrainian Literature Vinnytsia Mykhailo Kotsuibynskyi State Pedagogical University 32, Ostrozhskogo str., Vinnytsia, 21100, Ukraine

Khotsianivska I. V., Candidate of Philology Sciences, Associate Profess or at the Chair of the Ukrainian Culture and History Vinnytsia Mykhailo Kotsuibynskyi State Pedagogical University 32, Ostrozhskogo str., Vinnytsia, 21100, Ukraine 